\title{
New localities for Crustacea Decapoda in the Magellan region, southern South America*
}

\author{
JULIO H. VINUESA, GUSTAVO A. LOVRICH and FEDERICO TAPELLA \\ Consejo Nacional de Investigaciones Científicas y Técnicas (CONICET), Centro Austral de Investigaciones Científicas \\ (CADIC), CC 92 - (9410) Ushuaia, Tierra del Fuego, Argentina. E-Mail: jvinuesa@arnet.com.ar
}

\begin{abstract}
SUMMARY: We report the occurrence of Lithodes turkayi (Anomura), Libidoclaea granaria, and C. edwardsii (Brachyura), in the Beagle Channel. This observation extends their range of distribution south of the previously reported limit of the Straits of Magellan. Acanthocyclus albatrossis (Brachyura) occurs south of Isla Navarino and also in the Beagle Channel, however in a particular habitat of its northern coast. The occurrence of Lithodes confundens (formerly identified as $L$. antarcticus) north of the eastern entrance of the Straits of Magellan is also reported. We extend its range of distribution northerly and its bathymetric distribution to the intertidal.
\end{abstract}

Key words: Southwestern Atlantic, southeastern Pacific, Subantarctic, Anomura, Brachyura, crabs.

RESUMEN: Nuevas localidades para Crustacea DeCapoda en la Región Magallánica, en la América del Sur ausTRAL. - En este artículo describimos la presencia de Lithodes turkayi (Anomura), Libidoclaea granaria, y Cancer edwardsii (Brachyura) en el Canal del Beagle, que extienden su rango de distribución al sur del Estrecho de Magallanes. Notificamos aquí la presencia de Acanthocyclus albatrossis (Brachyura) en un único habitat con particulares características de la costa norte del Canal del Beagle. También describimos la aparición de Lithodes confundens (registrado previamente como Lithodes antarcticus) en el intermareal al norte de la entrada oriental del Estrecho de Magallanes, extendiendo su rango de distribución hacia el norte y su distribución batimétrica hasta el intermareal.

Palabras clave: Atlántico sudoccidental, Pacífico sudoriental, subantártico, Anomura, Brachyura, cangrejos.

\section{INTRODUCTION}

The inventory of Crustacea Decapoda of the Magellan region can be considered to be almost complete (Arntz and Ríos, 1997). However, some localities of the distribution of Decapoda should be added to the distribution lists currently in use (Vinuesa, 1977; Retamal, 1981; Boschi et al., 1992; Spi-

\footnotetext{
*Accepted February 10, 1999.
}

vak, 1997; Gorny, 1999) to know their exact range of distribution in the southern tip of South America and therefore the paths of interchange between both oceans. In this article we provide new localities and extend the range of distribution of 4 species of benthic Decapoda, previously reported in the Magellan zoogeographic Province. We also give the only locality of the northern coast of the Beagle Channel where Acanthocyclus albatrossis Rathbun, 1898 occurs. 


\section{MATERIAL}

All of the following species are part of the collection of the Laboratorio de Biología de Crustáceos of the Centro Austral de Investigaciones Científicas (CADIC), in Ushuaia.

Infraorder ANOmURA H. Milne Edwards, 1832 Family Lithodidae Samouelle, 1819

Lithodes confundens Macpherson, 1988

Previous known distribution: south of Islas Malvinas (Falklands I.) at $54^{\circ} 02^{\prime} \mathrm{S}, 58^{\circ} 40^{\prime} \mathrm{W}$ and in the Strait of Magellan on muddy bottoms, from 50 to 119 m depth (Macpherson, 1988).

Between 12-14 December 1997, 222 males from 23.7 to $145.0 \mathrm{~mm}$ carapace length (CL) and 104 females between 38.4 and $94.4 \mathrm{~mm}$ CL were caught near Monte Tigre $\left(51^{\circ} 21^{\prime} \mathrm{S}\right.$; $\left.69^{\circ} 02^{\prime} \mathrm{W}\right), 120 \mathrm{~km}$ north of the eastern entrance of the Strait of Magellan. Specimens were caught by tangle nets and by hand in the intertidal during ebbtide, when they left tidal pools at the moment of draining. One hundred specimens were found in mating couples. Further information was reported by Lovrich et al. (1998).

Lithodes turkayi Macpherson, 1988

Previous known distribution: off the Pacific coast of Chile (ca. $32^{\circ} \mathrm{S}$; Revuelta and Andrade, 1978), Strait of Magellan (Campodónico and Guzmán, 1972) and off Islas Malvinas (Falklands I.; Macpherson, 1988), from 70 to $600 \mathrm{~m}$ depth.

On 16 August 1997, 7 males from 57.4 to 72.5 $\mathrm{mm} \mathrm{CL}$ and 22 ovigerous females from 40.3 to 69.0 $\mathrm{mm} \mathrm{CL}$ were collected in the Beagle Channel $\left(54^{\circ} 54.3^{\prime} \mathrm{S} ; 68^{\circ} 36.0^{\prime} \mathrm{W}\right)$ at $230 \mathrm{~m}$ depth with commercial traps used for fishing kingklip Genypterus blacodes (Schneider, 1801).

Infraorder BRACHYURA Latreille, 1803

Family Majidae Samouelle, 1819

Libidoclaea granaria Milne Edwards and Lucas, 1842

Previous known distribution: in the Pacific, from Valparaíso to the Strait of Magellan, and in the Atlantic from the Strait of Magellan to Golfo San Matías (Retamal, 1981), and off Buenos Aires Province (Boschi et al., 1992).

On 18 July 1985, one male of $92.5 \mathrm{~mm}$ CL, 81.2 $\mathrm{mm}$ carapace width $(\mathrm{CW})$ was caught at $60 \mathrm{~m}$ depth near Islotes Lucas $\left(54^{\circ} 52.7^{\prime} \mathrm{S} ; 68^{\circ} 12.2^{\prime} \mathrm{W}\right)$ by com- mercial traps for fishing king crabs. Captured along with specimens of Lithodes santolla.

Family Belliidae Dana, 1852 Acanthocyclus albatrossis Rathbun, 1898

Previous known distribution: from Talcahuano, Chile (Retamal, 1981) to Seno Grandi Isla Navarino (55²`S; 6755’S; Garth et al., 1967), and Islas Malvinas (Falkland Is.) (Boschi et al., 1992).

A sample of 24 male specimens, ranging from 4.3 to $17.8 \mathrm{~mm}$ of CL and 34 female specimens, with CL from 9.5 to $18.5 \mathrm{~mm}$, with only one ovigerous female were captured on 12 February 1998 in Bahia Varela $\left(54^{\circ} 52.2^{\prime} \mathrm{S} ; 67^{\circ} 15.0^{\prime} \mathrm{W}\right)$. A grouping of this species was found in intertidal mussel beds in a beach with an even slope. Crabs were inside interstices formed by mussels, their bissus and (or) stones. Crabs were found in an environment sheltered from waves and strong currents. This is the only locality on the northern coast of the Beagle Channel, Argentina that this species was found.

Family Cancridae Latreille, 1803

Cancer edwardsii Bell, 1835

Previous known distribution: from Ecuador to Strait of Magellan (Retamal, 1981).

One male of $78.1 \mathrm{~mm} \mathrm{CL}, 122 \mathrm{~mm} \mathrm{CW}$, formalin fixed weight $350 \mathrm{~g}$. Caught on 30 August 1990 at $30 \mathrm{~m}$ depth near Islotes Haskenyeska (54 54.3'S; $67^{\circ} 08.9^{\prime} \mathrm{W}$ ) by a commercial trap for fishing king crabs. Captured with $>100$ specimens of Paralomis granulosa, which occurred in the same trap.

\section{DISCUSSION}

The occurrence of Lithodes turkayi, Libidoclaea granaria, and C. edwardsii in the Beagle Channel extends their range of distribution south to the previously reportedly limit of the Strait of Magellan (Retamal, 1981; Boschi et al., 1992).

Although the southern limit of the distribution of Acanthocyclus albatrossis is the Seno Grandi ( $55^{\circ} 12^{\prime} \mathrm{S}$; $67^{\circ} 56^{`} \mathrm{~W}$; Garth et al., 1967), this is the first mention of its occurrence in the Beagle Channel, Argentina. We believe that the environment of Bahía Varela is unique on the northern coast of the Beagle Channel. By contrast, in very similar habitats but with a greater energy of waves and currents, only the hymenosomatid Halicarcinus planatus (Fabricius, 1775) occurs. 
Lithodes turkayi Macpherson, 1988 is morphologically very similar to $L$. murrayi Henderson, 1888 (see Macpherson, 1988), and the latter species is the only lithodid from the high Antarctic (Klages et al., 1995). Therefore, in future studies we recommend meticulous morphometric examinations of specimens from all the range of distribution of these species to resolve whether they belong to the same species, and whether this/these species has/have Antarctic and Subantarctic distribution.

The occurrence of Lithodes confundens here reported extends its range of distribution northerly and its bathymetrical distribution range to the intertidal. Moreover, to our knowledge this is the only lithodid species that occur in this habitat.

So far, Lithodes santolla (Molina, 1782) (formerly L. antarcticus Jacquinot 1844 ) and $L$. confundens were confused because of their very similar morphological characters, and thus individuals may have been misidentified as L. santolla $(=L$. antarcticus). From anecdotal evidence, Lithodes confundens may occur from the latitude of Puerto San Julian (ca. $49^{\circ} \mathrm{S}$ ) to Cabo San Pablo $\left(54^{\circ} 20^{\prime} \mathrm{S}\right.$, personal observations). Off the Patagonian Atlantic coast $L$. santolla occurs in the Golfo San Jorge between $45^{\circ}$ and $47^{\circ} \mathrm{S}$ (Vinuesa, 1985) and off the Atlantic coast of Tierra del Fuego (Cabo San Pablo, pers. obs.). Lithodes santolla has occurred at high densities in the Strait of Magellan and south of the Isla Grande (Tierra del Fuego). Hence, it is probable that L. santolla exhibits a disjointed distribution off the Atlantic Patagonian coast south to $45^{\circ} \mathrm{S}$ : one population in the Golfo San Jorge and the other(s) in the surrounding waters of Tierra del Fuego. Furthermore, from the evidence presented here and by Macpherson (1988), L. confundens likely occurs in the Strait of Magellan. Detailed surveys are needed to resolve the pattern of mixing, occurrence and abundance of both species in the Strait of Magellan and south Atlantic waters.

\section{ACKNOWLEDGEMENTS}

JHV and GAL are Senior Researchers of the Consejo Nacional de Investigaciones Científicas y Técnicas (CONICET) and FT has a postgraduate Fellowship of the CONICET.

\section{REFERENCES}

Arntz, W. and C. Ríos. - 1997. Conclusions of the working groups. Workshop "Investigaciones en Biología Marina en el área de Magallanes en relación con la Antártida". Punta Arenas, 7-11 April 1997. 24 pp (mimeo).

Boschi, E.E., C.E. Fischbach and M.I. Iorio. - 1992. Catálogo ilustrado de los crustáceos estomatópodos y decápodos marinos de Argentina. Frente Marítimo, 10 A: 7-94.

Campodónico, I. and L.Guzmán. - 1972. Lithodes murrayi Henderson, 1888, nuevo litodido para la Patagonia Austral de Chile. Ans. Inst. Pat., Punta Arenas (Chile), 5: 215-222.

Garth, J.S., J. Haig and J.C. Yaldwyn. - 1967. The Decapod Crustacea of the Royal Society Expedition to Southern Chile, 195859. Trans. Roy. Soc. New Zealand. Zool., 8: 169-186.

Gorny, M. - 1999. On the biogeography and ecology of the Southern Ocean decapod fauna. Sci. Mar., this volume.

Klages, M., J. Gutt, A. Starmans and T. Bruns. - 1995. Stone crabs close to the Antarctic continent: Lithodes murrayi Henderson, 1888 (Crustacea; Decapoda; Anomura) off Peter I Island (68 $\left.51^{\prime} \mathrm{S}, 90^{\circ} 51^{\prime} \mathrm{W}\right)$. Polar Biol., 15: 73-75.

Lovrich, G.A., J.H. Vinuesa, F. Tapella and A. Chizzini. - 1998. La centolla Lithodes confundens en el intermareal sudatlántico de Santa Cruz, Argentina. Informe 1997. Contrib. Cient. CADIC, 30: 1-16.

Macpherson, E. - 1988. Revision of the family Lithodidae Samouelle, 1819 (Crustacea, Decapoda, Anomura) in the Atlantic Ocean. Monogr. Zool. Mar., 2: 9-153.

Retamal, M.A. 1981. - Catálogo ilustrado de los crustáceos decápodos de Chile. Gayana Zool., 44: 1-110.

Revuelta, G. and H. Andrade. - 1978. Nueva localidad para Lithodes murrayi Henderson en el Pacífico Sur Oriental (Crustacea, Decapoda, Anomura, Lithodidae). Not. Mus. Nac. Hist. Nat. Santiago, 261: 1-9.

Spivak, E. - 1997. Los crustáceos decápodos del Atlántico sudoccidental $\left(25^{\circ}-55^{\circ} \mathrm{S}\right)$ : distribución y ciclos de vida. Invest. Mar., Valparaíso, 25: 69-91.

Vinuesa, J.H. - 1977. Aportes al conocimiento de los crustáceos decápodos de Tierra del Fuego con algunas observaciones zoogeográficas. Physis Secc. A., 36 (92): 9-19.

Vinuesa, J.H. - 1985. Differential aspects of the southern king crab (Lithodes antarcticus) in two latitudinally separated locations. In: B. Melteff (ed.), Proc. Int. King Crab Symp. Alaska. Alaska Sea Grant Report 85-12, pp. 267-280. Alaska Sea Grant College Program. 